\title{
EFEKTIVITAS PELAKSANAAN BLENDED LEARNING DI SMAN 4 SINGARAJA
}

\author{
Oleh: \\ I Wayan Redhana ${ }^{1 *}$, I Nyoman Suardana \\ 1Program Studi Pendidikan Kimia, Universitas Pendidikan Ganesha, Bali Indonesia \\ redhana.undiksha@gmail.com
}

\begin{abstract}
Abstrak
Abstrak

Tujuan dari Program Kemitraan Masyarakat ini adalah untuk mendeskripsikan efektivitas implementasi blended learning di SMAN Singaraja Kabupaten Buleleng Bali.Untuk itu, lima mata pelajaran dijadikan pilot projek pelaksanaan blended learning. Kelima mata pelajaran tersebut adalah mata pelajaran Kimia, Fisika, Biologi, Bahasa Inggris dan Agama. Pemilihan kelima mata pelajaran ini sebagai pilot projek didasarkan atas kesiapan mitra pengampu mata pelajaran untuk melaksanakan blended learning dan kompetensi mitra dalam penguasaan teknologi informasi. Sebelum melaksanakan blended learning, mitra membuat konten online terlebih dahulu. Selama pembuatan konten online ini, mitra didampingi oleh pelaksana PKM. Flatform yang digunakan untuk membuat konten online adalah google classroom. Pelaksanaan blended learning menggunakan model flipped classroom. Pada model flipped classroom ini, siswa mempelajari materi terlebih dahulu di rumah yang diunggah secara online oleh mitra. Materi yang diunggah secara online berupa bahan/buku ajar, video pembelajaran, lembar kerja siswa, dan tugas-tugas terkait dengan topik yang dipelajari. Hasil dari pelaksanaan blended learning ini adalah sebagai berikut. Skor rata-rata keterampilan mitra dalam mengimplementasikan blended learning masing-masing sebesar 2,72 dan 4,38 dengan skor gain ternormalisasi 0,73 (tergolong tinggi). Hasil belajar siswa telah mencapai ketuntasan belajar klasikal sebesar 87,50\% (melampaui KKM klasikal 85\%). Siswa merespon implementasi blended learning dengan sangat baik (skor rata-rata 4,35).
\end{abstract}

Kata Kunci: blended learning, flipped classroom, Program Kemitraan Masyarakat

\begin{abstract}
The purpose of this Community Partnership Program was to describe the effectiveness of the implementation of blended learning at SMAN Singaraja, Buleleng, Bali. For that, five subjects were used as pilots for the implementation of blended learning projects. They were Chemistry, Physics, Biology, English and Religion. The selection of them as pilot projects was based on the readiness of subject matter partners to carry out blended learning and partners' competencies in mastering information technology. Before implementing the blended learning, the partners created online contents of the subjects. During the creation of these online contents, the partners were guided by Community Partnership Program implementers. The platform used to create online content was google classroom. The implementation of blended learning used the flipped classroom model. In this model, students learnt the contents first at home uploaded online by partners. The contents uploaded online in the forms of learning materials, textbooks, learning videos, students' worksheets, and assignments related to the topic being studied. The results of implementation of the blended learning were as follows. The average score of partners' skills in implementing the blended learning were 2.72 and 4.38, respectively, with a normalized gain score of 0.73 (relatively high). Students' learning outcomes had reached the classical learning completeness of $87.50 \%$ (exceeding the classical completeness criteria of $85 \%$ ). Students responded to the implementation of blended learning very well (the average score of 4.35).
\end{abstract}

Keywords: blended learning, Community Partnership Program, flipped classroom 


\section{PENDAHULUAN}

Pembelajaran yang dilakukan oleh kebanyakan mitra saat ini adalah pembelajaran tatap muka. Pada pembelajaran tatap muka ini terjadi pertemuan antara mitra (guru) dan siswa dan biasanya berlangsung dalam ruang kelas. Pembelajaran ini dapat mendorong terjadinya interaksi yang optimun antara mitra dan siswa serta antara siswa dan siswa. Pada pembelajaran tatap muka ini, mitra dapat mengenal siswanya dengan baik. Yang paling utama adalah siswa mendapat bimbingan oleh mitra secara langsung dalam memahami materi yang dipelajari. Pembelajaran tatap muka ini sering disebut sebagai pembelajaran tradisional.

Pembelajaran tatap muka yang dilaksanakan selama ini menggunakan pendekatan saintifik. Pendekatan ini dilaksanakan sesuai dengan tuntutan Kurikulum 2013. Menurut hasil-hasil penelitian, pendekatan saintifik sangat efektif meningkatkan hasil belajar siswa, yang meliputi aspek kognitif, afektif, dan psikomotorik. Dalam pendekatan saintifik ini, mitra dapat menggunakan model-model pembelajaran yang berpusat pada siswa, seperti model pembelajaran berbasis masalah, model pembelajaran berbasis projek, model pembelajaran penemuan, dan model pembelajaran inkuiri.

Di balik semua keunggulan dari model pembelajaran tatap muka, pembelajaran ini juga memiliki kelemahan dalam pelaksanaannya. Kelemahan tersebut adalah pembelajaran berlangsung dalam ruang dan waktu yang kaku. Artinya, jika tempat tidak ada, maka pembelajaran tidak bisa berlangsung. Demikian juga jika mitra tidak bisa mengajar dan salah seorang atau beberapa orang siswa tidak bisa belajar pada jadwal yang ditetapkan, maka pembelajaran tidak bisa berlangsung. Belum lagi materi pelajaran yang padat sehingga tidak seluruhnya dapat diselesaikan dalam pertemuan tatap muka. Selain itu, kegiatankegiatan seperti ulang tahun sekolah sering pembelajaran ditiadakan oleh pihak sekolah dengan alasan siswa dan mitra melaksanakan berbagai jenis lomba dan kegiatan. Ini akan mengurangi waktu efektif tatap muka yang berlangsung di kelas.

Di lain pihak, perkembangan internet telah dimanfaatkan dalam pembelajaran. Salah satu pemanfaatan internet dalam pembelajaran adalah pembelajaran online.
Pembelajaran online ini di Indonesia telah dirintis oleh Universitas Terbuka. Pembelajaran online adalah pembelajaran berlangsung secara online dan hampir tidak ada pertemuan tatap muka di kelas. Pembelajaran online ini mampu mengatasi kendala dari segi ruang dan waktu. Artinya. siswa dapat belajar secara fleksibel kapan saja dan dan di mana saja.

Pelaksanaan pembelajaran online ini bukan tidak ada kekurangan. Masih banyak kekurangan yang ditemukan pada pembelajaran online, seperti siswa menjadi terasing, dan kurang melatih aspek sikap dan keterampilan. Oleh karena itu, pembelajaran online penuh kurang sesuai dilaksanakan untuk mengembangkan karakter dan keterampilan siswa.

Dengan mengambil kelebihan dari masing-masing pembelajaran tatap muka dan online penuh, lebih bijak jika kedua pembelajaran ini digabungkan. Penggabungan kedua pembelajaran ini disebut sebagai pembelajaran campuran atau blended learning. Pembelajaran dikatakan sebagai pembelajaran campuran atau blended learning jika porsi pembelajaran yang diantarkan secara online berkisar antara 30 hingga $79 \%$. Kelebihan yang dimiliki oleh pembelajaran tatap muka dapat mengatasi kelemahan yang dimiliki oleh pembelajaran online. Sebaliknya, kelebihan yang dimiliki oleh pembelajaran online justru dapat mengatasi kelemahan yang dimiliki oleh pembelajaran tatap muka. Oleh karena itu penggabungan kedua jenis pembelajaran ini menjadikan pembelajaran campuran (blended learning) lebih berdaya guna (powerful).

SMAN 4 Singaraja telah memiliki jaringan internet yang sangat kuat dan juga didukung oleh sumber daya manusia atau tenaga pengajar yang kompeten. SMAN 4 Singaraja sebagai salah satu sekolah favorit di Singaraja siap melaksanakan pembelajaran campuran. Masalah yang dipecahkan melalui kegiatan Program Kemitraan Masyarakat ini adalah "Bagaimana efektivitas pelaksanaan blended learning di SMAN 4 Singraaja?"

\section{METODE}

Pelaksanaan blended learning di SMAN 4 Singaraja diawali oleh kegiatan pelatihan tentang pembuatan RRP dengan pendekatan saintifik (Gambar 1) dan pembuatan konten online oleh lima orang guru (mitra) yang siap melaksanakan blended learning sebagai pilot projek (Gambar 2). Lima orang guru (mitra) 
yang dilatih ini masing-masing mengampu mata pelajaran Kimia, Fisika, Biologi, Bahasa Inggris, dan Agama. Pemilikan kelima orang guru (mitra) ini didasarkan atas kesiapan mitra dan kemampuan penguasaan teknologi informasi oleh guru yang bersangkutan dibandingkan dengan guru-guru lainnya. Jika pilot projek ini berhasil, maka kelima orang guru (mitra) ini akan bertindak sebagai instruktur yang mendiseminasikan praktikpraktik baik (best practices) kepada guru-guru lainnya.

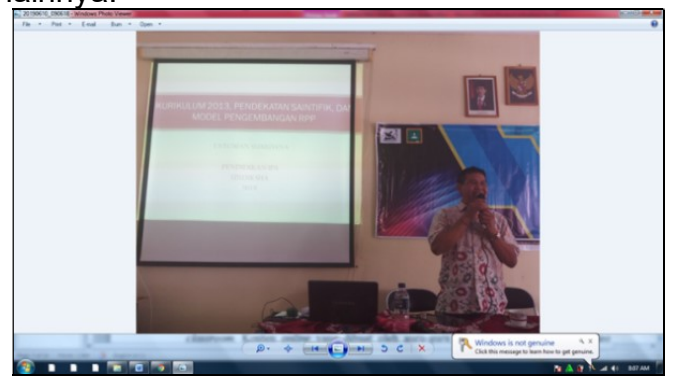

Gambar 1. Pelatihan pembuatan RPP dengan pendekatan saintifik

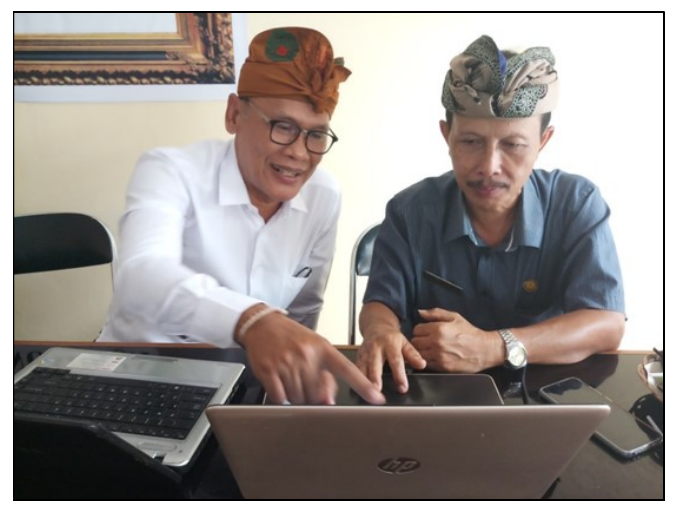

Gambar 2. Pendampingan pembuatan konten online

1) Guru menginformasikan secara online tentang tujuan pembelajaran yang harus dicapai oleh siswa, cakupan materi yang dipelajari oleh siswa, dan sistem penilaian yang dilakukan oleh guru.

2) Guru menyampaikan fenomena untuk menstimulasi belajar siswa (Tahap Mengamati).

3) Siswa mengajukan pertanyaan/masalah (Tahap Menanya).

4) Siswa mengumpulkan data atau informasi dengan mempelajari materi yang telah diunggah oleh guru secara online. Materi dapat berupa antara lain bahan/buku ajar, video pembelajaran,lembar kerja siswa, dan tugas-tugas (Tahap mengumpulkan Data).
5) Guru melaksanakan pembelajaran tatap muka di kelas. Pembelajaran tatap muka diawali dengan kegiatan pendahuluan yang meliputi pengingatan kembali tujuan pembelajaran, cakupan materi yang dipelajari, sistem penilaian yang akan dilakukan, dan membentuk kelompok belajar yang anggotanya terdiri atas 4-5 orang siswa.

6) Guru menugaskan siswa dalam kelompok mendiskusikan pemecahan masalah yang telah dikerjakan secara online. Guru memantau jalannya diskusi sambil memberikan bimbingan kepada kelompok siswa yang belum memahami materi pelajaran dengan baik (Tahap Mengasosiasi).

7) Guru meminta beberapa kelompok menyajikan hasil diskusinya di depan kelas terkait dengan masalah yang dipecahkan. Dalam diskusi kelas ini, guru memberikan arahan dan bimbingan untuk memperbaiki konsep-konsep atau pemahaman siswa yang masih keliru (Tahap mengomunikasikan).

8) Guru meminta siswa menarik simpulan dari materi yang telah dipelajari.

9) Pada kegiatan penutup, guru meminta siswa merangkum materi yang telah dipelajari, melakukan refleksi terhadap kegiatan pembelajaran yang telah dilakukan baik secara online maupun tatap muka, dan menginformasikan materi yang akan dipelajari pada pembelajaran berikutnya.

10) Guru-guru selanjutnya melaksanakan tes secara online.

Data yang diperoleh dari kegiatan ini berupa skor hasil belajar siswa (dibatasi pada aspek kognitif). Data yang diperoleh melalui kegiatan ini dianalisis secara deskriptif. Efektivitas pelaksanaan blended learning ini diukur dari pencapaian kriteria ketuntasan minimal (KKM) klasikal 85\%. Pelaksanaan blended learning dikatakan efektif, jika KKM klasikal minimal 85\% telah dapat dicapai oleh siswa melalui kegiatan ini. KKM 85\% merupakan persentase siswa yang telah mencapai KKM individu (70) minimal sebanyak 85\%. Pada akhir seluruh pelaksanaan blended learning diedarkan angket untuk mengetahui pendapat mitra dan siswa tentang efektivitas pelaksanaan blended learning. Angket menggunakan lima skala Likert. Data ini dianalisis secara deskriptif dengan menghitung skor rata-rata dan standar deviasi kemudian dikelompokkan berdasarkan kategori sangat kurang (1,0- 
$1,80)$, kurang $(1,81-2,60)$, cukup $(2,61-3,40)$, baik $(3,41-4,20)$, dan sangat baik $(4,21-5,0)$.

\section{HASIL DAN PEMBAHASAN}

\section{Hasil Kegiatan}

Kegiatan ini merupakan pelaksanaan blended learning di SMAN 4 Singaraja. Kegiatan dilakukan dalam dua tahap. Pertama adalah pembuatan konten online dan kedua adalah implementasi blended learning. Berikut disajikan hasil dari kegiatan pertama, yaitu pembuatan konten online oleh mitra yang menjadi pilot projek pada kegiatan ini.

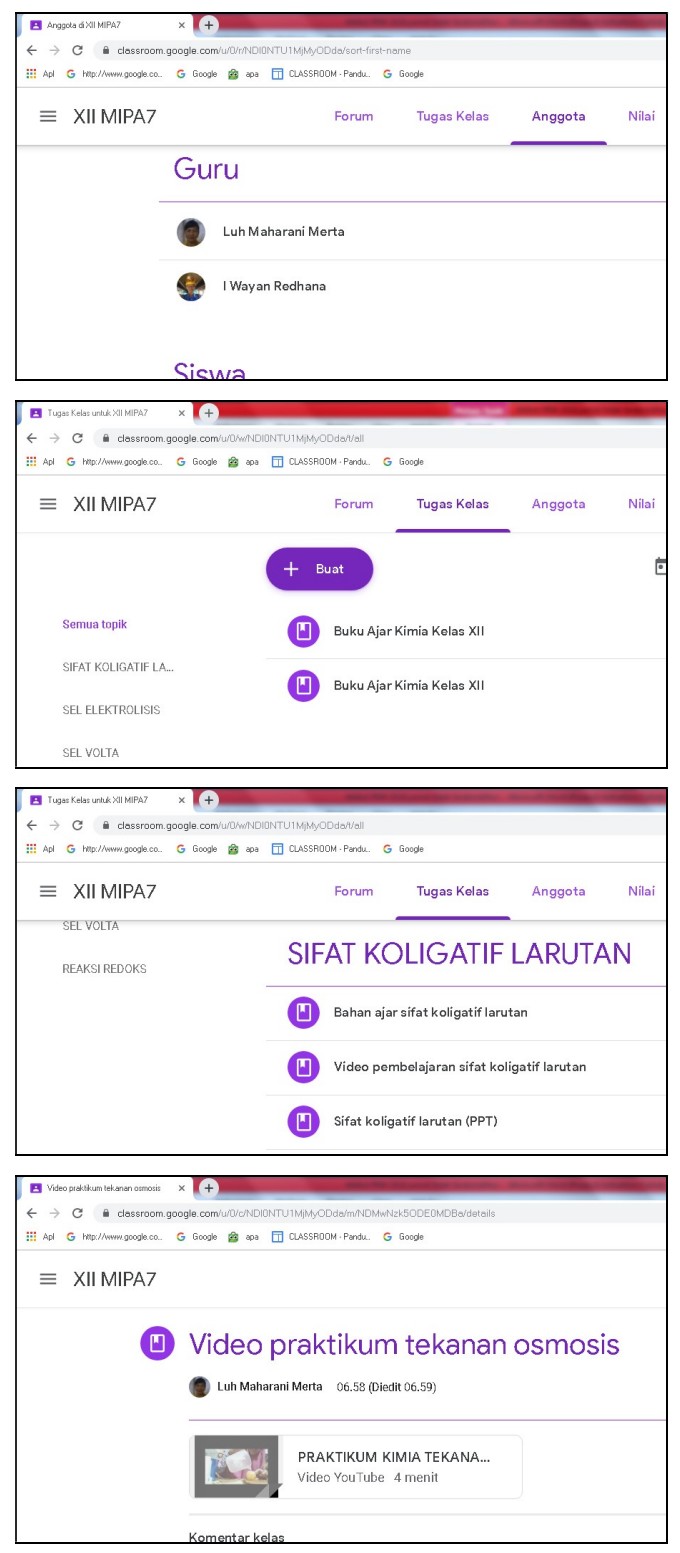

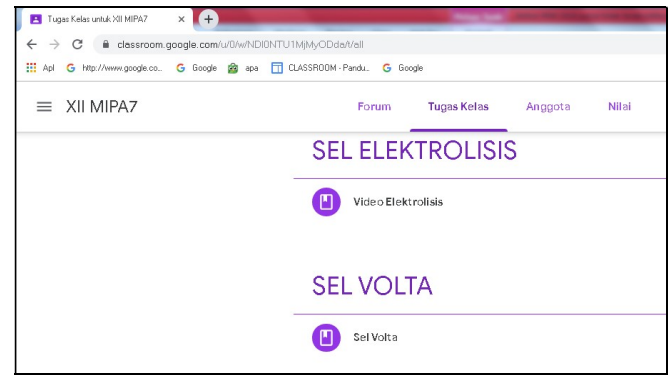

Gambar 3. Konten online mata pelajaran Kimia
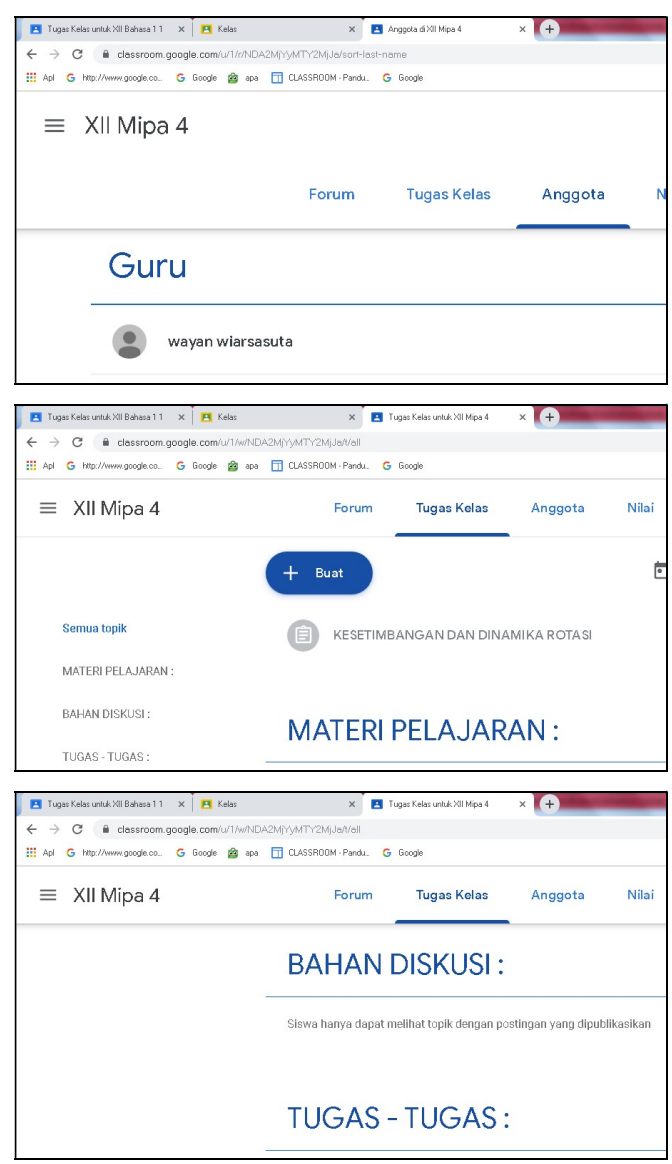

Gambar 4. Konten online mata pelajaran Fisika

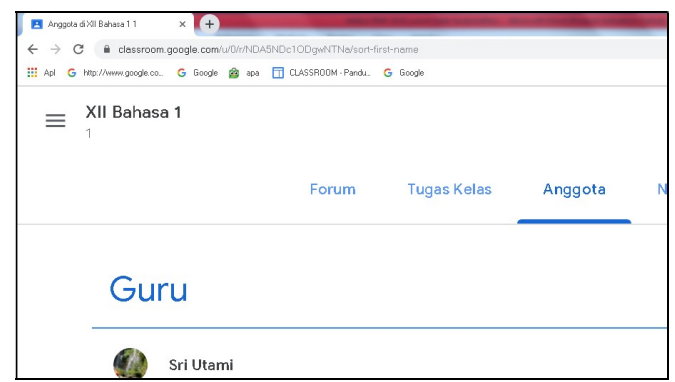



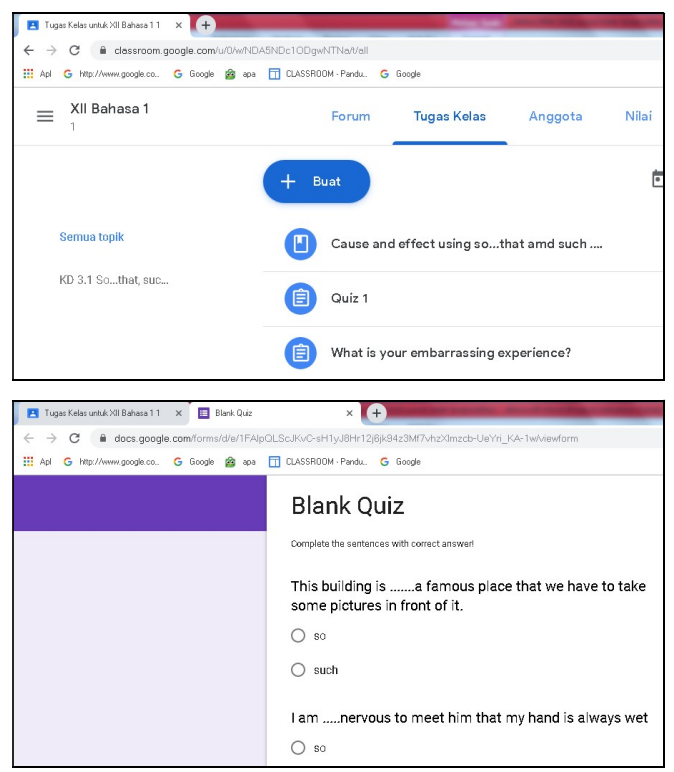

Gambar 5. Konten online mata pelajaran Bahasa Inggris

Mitra memiliki keterampilan yang sangat baik dalam mengimplementasikan blended learning. Hal ini dapat dilihat dari hasil penilaian keterampilan mitra sebelum dan setelah implementasi blended learning masing-masing sebesar 2,72 (SD 0,15) dan 4,38 (SD 0,14) dengan skor gain ternormalisasi 0,73 (kategori tinggi) (Gambar 6). Keterampilan mitra dalam mengimplementasikan blended learning setelah implementasi tergolong sangat baik.

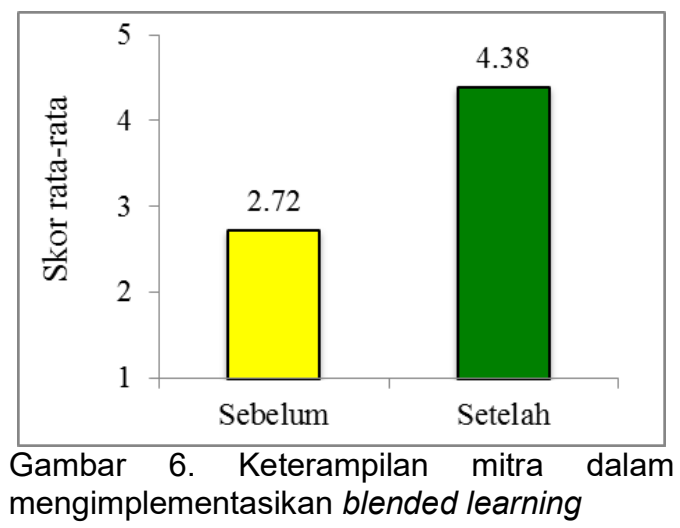

Sebagai pengaruh dari implementasi blended learning ini, hasil belajar siswa menunjukkan kemajuan yang sangat baik. Ini dapat dilihat dari skor rata-rata hasil belajar siswa sebesar 81,23 (SD 8,76). Dengan kriteria ketuntasan minimal (KKM) individu sebesar 70, maka diperoleh KKM klasikal sebesar sebesar $87,50 \%$ (melampaui KKM
85\%). Ini membuktikan bahwa blended learning sangat efektif dan efisien dalam meningkatkan hasil belajar siswa. Siswa merespon implementasi blended learning ini dengan sangat baik (skor rata-rata 4,35; SD $0,07)$.

\section{Pembahasan}

Pelaksanaan blended learning di SMAN 4 Singaraja berlangsung dengan baik. Mitra sangat antusias melaksanakan blended learning. Hal ini disebabkan oleh blended learning merupakan pembelajaran yang baru bagi mereka. Selain itu, blended learning mendorong terjadinya interaksi yang efektif antara siswa dengan siswa dan antara siswa dengan mitra. Dengan diunggahnya materi dan tugas-tugas secara online, siswa dapat mengunduh seluruh materi baik berupa buku, LKS, video youtube, maupun konten dari URL tertentu. Dengan materi dan tugas-tugas yang dapat diunduh secara online, siswa dapat mempelajari materi dan mengerjakan tugas-tugas terlebih dulu. Di dalam kelas tatap muka, mitra dan siswa tinggal melakukan diskusi untuk mendalami materi yang dipelajari. Inilah yang disebut sebagai blended learning model flipped classroom (kelas terbalik).

Penerapan blended learning dapat memecahkan masalah yang dihadapi oleh mitra. Masalah-masalah tersebut adalah sebagai berikut. Pertama, padatnya materi pelajaran dengan jam pelajaran yang terbatas. Dengan telah dipelajari materi dan tugas-tugas terlebih dahulu di rumah oleh siswa sebelum pelajaran, akan menghemat waktu pembelajaran. Selain itu, pembelajaran berlangsung dengan lebih efektif. Kedua, kehilangan jam pelajaran oleh mitra karena adanya kegiatan lain atau mitra tidak masuk dapat diatasi dengan blended learning. Mitra dapat melaksanakan pembelajaran online sebagai pengganti pembelajaran tatap muka. Ketiga, dengan blended learning, partistipasi siswa dalam belajar meningkat baik saat belajar di rumah (online) maupun di kelas (tatap muka). Siswa menjadi lebih aktif berdiskusi di kelas karena mereka telah belajar materi dan tugas-tugas di rumah (online). Dengan cara ini hasil belajar siswa akan dapat ditingkatkan.

Efektivitas blended learning telah dilaporkan oleh beberapa peneliti. Misalnya, blended learning mampu meningkatkan terjadinya interaksi kelas (Gómez \& Duart, 2011), sikap positif siswa terhadap pelajaran (Tselios et al., 2011), prestasi belajar siswa 
(Sen, 2011; Syarif, 2012; Lee \& Hung, 2015; Hinampas et al., 2018; Oweis, 2018; AlMadani, 2015; Khader, 2016; Ceylan \& Kesici, 2017; Nguyen, 2017; Harahap et al., 2019), motivasi belajar siswa (Lee \& Hung, 2015; Oweis, 2018; Gambari et al., 2017), kepuasan belajar belajar siswa (Kintu et al., 2017; Rahman, 2018), keterampilan kerja laboratorium (Hinampas et al., 2018), dan spiritual dan karakter siswa (Vasantan, 2016; Rahman, 2018). Selain itu, blended learning memungkinkan siswa belajar secara fleksibel (tanpa terikat oleh waktu dan ruang), sesuai dengan kebutuhan siswa, aktivitas belajar siswa lebih tinggi, bimbingan oleh mitra lebih optimal, peningkatan kreativitas siswa, persiapan belajar siswa lebih baik, pengembangan keterampilan abad ke-21, bekerja tanpa kertas (paperless), komunikasi yang lebih efektif, pemahaman yang lebih mendalam, dan berlatih mengelola informasi menggunakan teknologi dan internet.

\section{SIMPULAN DAN SARAN}

\section{Simpulan}

Berdasarkan hasil-hasil yang dicapai dalam kegiatan ini dapat disimpulkan sebagai berikut. Mitra memiliki keterampilan yang sangat baik dalam mengimplementasikan blended learning. Blended learning mampu meningkatkan hasil belajar siswa dengan mencapai ketuntasan belajar klasikal sebesar $87,50 \%$ yang melampaui KKM 85\%. Siswa merespon implementasi blended learning yang diterapkan oleh mitra dengan sangat baik.

\section{Saran}

Berdasarkan hasil-hasil yang dicapai dari kegiatan PKM ini dapat disarankan bahwa mitra dapat mengimplementasikan blended learing ini untuk meningkatkan hasil belajar siswa.

\section{DAFTAR PUSTAKA}

Al-Madani, F. M. 2015. The Effect of blended learning approach on fifth grade students' academic achievement in my beautiful language textbook and the development of their verbal creative thinking in Saudi Arabia. Journal of International Education Research, 11(4), 253-260.

Ceylan, V. K. \& Kesici, A. E. 2017. Effect of blended learning to academic achievement. Journal of Human Sciences, 14(1), 308-320.

Gambari, A., I. \& Shittu, A. T., Ogunlade, O. O., \& Osunlade, O. R. 2017. Effectiveness of blended learning and elearning modes of instruction on the performance of undergraduates in Kwara State, Nigeria. Malaysian Online Journal of Educational Sciences, 5(1), 25-36.

Gómez, L. A. O. \& Duart, J. M. 2011. A hybrid approach to university subject learning activities. British Journal of Educational Technology, 42(2), 259-271.

Harahap, F., Nasution, F. E. A., \& Manurung, B. 2019. The effect of blended learning on student's learning achievement and science process skills in plant tissue culture course. International Journal of Instruction, 12(1), 521-538.

Hinampas, R. T., Murillo, C. R., Tan, D. A., \& Layosa, R. U. 2018. Blended learning approach: Effect on students' academic achievement and practical skills in science laboratories. International Journal of Scientific \& Technology Research, 7(11), 63-69.

Khader, N. S. 2016. The effectiveness of blended learning in improving students' achievement in third grade's science in Bani Kenana. Journal of Education and Practice, 7(35), 109-116.

Kintu, M. J., Zhu, C. \& Kagambe, E. 2017. Blended learning effectiveness: the relationship between student characteristics, design features and outcomes. International Journal of Educational Technology in Higher Education, 14(7), 1-20.

Lee, L. T. \& Hung, J. C. 2015. Effects of blended e-Learning: A case study in higher education tax learning setting. Human-centric Computing and Information Sciences, 5(13), 1-15.

Nguyen, V. A.. 2017. The impact of online learning activities on student learning outcome in blended learning course. Journal of Information \& Knowledge Management, 16(4), 1-21.

Oweis, T. I. 2018. Effects of using a blended learning method on students' achievement and motivation to learn english in Jordan: A pilot case study. Hindawi Education Research International, 1-7.

Rahman, A. M. A. 2018. English writing performance using blended learning in TVET education. Language Literacy, 2(1), 28-36. 
Sen, T. K. 2011. Application of blended and traditional class teaching approach in higher education and the student learning experience. International Journal of Innovation, Management and Technology, 2(2), 107-109.

Syarif, I. 2012. Pengaruh model blended learning terhadap motivasi dan prestasi belajar siswa SMK. Jurnal Pendidikan Vokasi, 2(2). 234-249.
Tselios, N., Daskalakis, S., \& Papadopoulou, M. 2011. Assessing the acceptance of a blended learning university course. Educational Technology \& Society, 14(2), 224-235.

Vasantan, P. 2016. Blended learning method based on local wisdom as a spiritual guidance holy trinity community in district bengkayang. Journal of Education, Teaching and Learning, 1(1), 36-40. 